\title{
Responses of Functional Genes Involved In Nitrogen Cycling To Green Manuring In Different Paddy Soils In South China
}

\section{Shun Li}

Nanjing Agricultural University

Hai Liang

Nanjing Agricultural University

\section{Yun Wang}

Nanjing Agricultural University

\section{Zihan Zhang}

Nanjing Agricultural University

\section{Lei Zhang}

Nanjing Agricultural University

\section{Guopeng Zhou}

Chinese Academy of Agricultural Sciences Institute of Agricultural Resources and Regional Planning

\section{Songjuan Gao}

Nanjing Agricultural University

\section{Weidong Cao ( $\square$ caoweidong@caas.cn)}

Chinese Academy of Agricultural Sciences Institute of Agricultural Resources and Regional Planning https://orcid.org/0000-0003-1787-9165

\section{Research Article}

Keywords: green manure, soil nutrients, $\mathrm{N}$ cycling, functional gene, rice yield

Posted Date: July 28th, 2021

DOI: https://doi.org/10.21203/rs.3.rs-740340/v1

License: (c) (1) This work is licensed under a Creative Commons Attribution 4.0 International License. Read Full License 


\section{Abstract}

Aims We studied the effects of green manuring on the nitrogen $(\mathrm{N})$ cycling process in different paddy soils.

Methods Field experiments conducted in Hunan, Jiangxi, Henan and Fujian provinces in south China to investigate the responses of rice yield, soil properties, and functional genes involved in $\mathrm{N}$ cycling to green manuring. The field experiments had four treatments, i.e., no fertilizer application (NF), using milk vetch (Astragalus sinicus L.) as green manure without chemical fertilizer (GM), winter fallow and chemical fertilizer (CF), and a combination of green manure and chemical fertilizer (GMCF).

Results The results showed that rice yield significantly increased in GMCF treatment. The copies of nifH gene significantly increased in GMCF in Jiangxi and Henan provinces. Ammonia oxidizing archaeal (AOA) amoA gene was predominant in all provinces compared with ammonia oxidizing bacterial (AOB). Compared with $\mathrm{CF}$ treatment, The copies of $\mathrm{AOB}-\mathrm{amo} A$ gene were reduced in $\mathrm{GMCF}$, indicating the inhibition of soil nitrification. The nirK gene was negatively correlated with $\mathrm{SOM}, \mathrm{TN}, \mathrm{NH}_{4}{ }^{+}-\mathrm{N}_{1} \mathrm{NO}_{3}{ }^{-} \mathrm{N}$ and $\mathrm{AP}$, indicating that the positive effects of green manure on soil nutrients caused the inhibition of denitrification process. The nirK gene was the most critical factor influencing rice yield among the tested functional genes, with a relative influence of $63.5 \%$. In comparison SOM was the most important factor (with a relative influence of $41.0 \%$ ) among soil chemical properties.

Conclusions In conclusion, the application of green manures changed the abundance of functional genes involved in the $\mathrm{N}$ cycling, and combined application with chemical fertilizer inhibited soil nitrification and denitrification.

\section{Introduction}

In south China, the utilization of milk vetch in the winter season has been proven to be an effective practice to increase the efficiency of chemical fertilizers and improve soil properties, which is of great significance to the sustainable production of paddy fields (Zhou et al., 2020; Yang et al., 2018a; Xie et al., 2016). The introduction of legume green manure may change the soil environment, affect soil nutrients availability, and profoundly influence $\mathrm{N}$ cycling process in the paddy soil due to the biological N fixation (Lupwayi et al., 2016; Sharifi et al., 2014). The application of leguminous green manures in the rotation system increased the $\mathrm{N}$ retention in the soil and reduced the $\mathrm{N}$ loss by strengthening the connection between plants and soil microorganisms (Vries et al., 2012; Liang et al., 2021). The $\mathrm{N}$ released from green manure decomposition usually enters the soil microbial biomass $\mathrm{N}$ pool first. Then part of it is absorbed and used by crops, and part of it is stored in the soil in the form of more stable organic $\mathrm{N}$ for a long time, such as microbial biomass N (Mcneill et al., 2008).

As a critical component of agroecosystems, the in-depth understanding of the $\mathrm{N}$ cycling process contributes to providing strategies for the prediction and management of N (Sun et al., 2015; Ishii et al., 2011; Ding et al., 2014). The Quantification of genes involved in $\mathrm{N}$ transformation is one of the essential methods in the mechanism study of $\mathrm{N}$ cycling (Bothe et al., 2000). Diazotrophs, ammonia oxidizers and denitrifiers are crucial microorganisms in soil $\mathrm{N}$ cycling. Diazotrophic microorganisms play an essential role in connecting the atmosphere and soil nitrogen circulation process, and nifH gene is the most commonly used functional biomarker to quantify diazotrophic microorganisms (Poly et al., 2001; Levy-Booth et al., 2014). Ammonia oxidization is the process of oxidizing ammonia nitrogen to nitrite, which is the beginning of nitrification. Ammonia oxidizing microorganisms include ammonia-oxidizing bacteria $(A O B)$ and ammonia-oxidizing archaea $(A O A)$, both the relative abundances of $A O A$ and $A O B$ are closely related to ammoxidation. They commonly used $\mathrm{AOA}$-amoA gene and $\mathrm{AOB}$-amoA gene markers for ammonia oxidizing microorganisms (Montoya, M., et al, 2021; Leininger et al., 2006; Prosser and Nicol, 2012). The denitrification process is catalyzed by many enzymes, and several genes can be used as biomarkers (Luo et al., 2018). Nitrite reductase and 
$\mathrm{N}_{2} \mathrm{O}$ - reductase use nirK and nos $\mathrm{Z}$ genes as a biomarker, respectively, and are regularly used to characterize denitrifying microbial communities (Qin, H.L., et al., 2021).

Fertilization management affects the structure and diversity of microorganisms involved in $\mathrm{N}$ cycling by changing soil properties (Liu et al., 2018; Fan et al., 2019). Previous studies showed that fertilization affects the microbes related to $\mathrm{N}$ cycling by affecting the soil properties (including soil pH, nutrients and types) (Chen et al., 2010; Levy-Booth et al., 2014; Che et al., 2015; Sun et al., 2015; Luo et al., 2018). Fertilization pattern, crop rotation and soil pH are important factors that regulate the responses of $\mathrm{N}$ cycling genes, and $\mathrm{N}$ fertilization significantly increased the abundance of AOA-amoA, AOB-amoA, nirk, nirS and nosZ genes (Yang et al., 2018a). Soil pH, C/N ratio and availability of soil nutrients play essential roles in the coexistence and assembly of $\mathrm{N}$-fixing microbial communities (Fan et al., 2018; Shu et al., 2012; Hu et al., 2018). AOA-amoA and AOB-amoA genes have different functional activities and physiological characteristics, and different substrate concentrations such as $\mathrm{NH}_{3}$ and $\mathrm{pH}$ may affect their contributions to nitrification (Martens-Habbena et al., 2009). Previous study showed that AOA dominates nitrification in acid soils, while AOB contributes more in neutral or alkaline soils (He et al., 2012).

Previous studies found that winter green manuring in the rice cropping systems changed the groups involved in nutrient cycling of soil microbial communities (Gao et al., 2021). The responses of $\mathrm{N}$ fixation and nitrification to green manuring were also studied in different types of soils (Gao et al., 2020a; Gao et al., 2020b; Yang et al., 2019). Former studies found that under the application of milk vetch, the input of rice straw increased the diversity of $\mathrm{N}$-fixing microorganisms, but the continuous input of chemical fertilizer reduced it (Yang et al., 2019). Although AOA was more abundant, $A O B$ contributed more to the nitrification process. The application of milk vetch with chemical fertilizer promoted the contribution of AOB to nitrification, with a relative contribution rate of $65 \%-79 \%$ (Gao et al., 2020a; Gao et al., 2020b). However, there were few reports about the responses of the entire $\mathrm{N}$ cycle to green manuring at different types of paddy soils. The joint experiments with rice-milk vetch cropping systems were established in Hunan, Jiangxi, Henan and Fujian provinces to explore the responses of rice yield, soil nutrients and functional genes involved in the $\mathrm{N}$ cycling to green manure. We aimed to clarify the effects of green manuring on the process of $\mathrm{N}$-fixation, nitrification and denitrification and explore the contributions of soil nutrients and functional genes involved in $\mathrm{N}$-fixation on rice yields among different sites at the regional scale.

\section{Materials And Methods}

\section{Field description}

The agricultural experimental stations for field experiments were located at four southern provinces in China, i.e., Hunan $\left(29.37^{\circ} \mathrm{N}, 112.39^{\circ} \mathrm{E}\right)$, Jiangxi $\left(28.19^{\circ} \mathrm{N}, 115.07^{\circ} \mathrm{E}\right)$, Henan $\left(32.12^{\circ} \mathrm{N}, 114.08^{\circ} \mathrm{E}\right)$, and Fujian $\left(26.08^{\circ} \mathrm{N}, 119.03^{\circ}\right.$ E). The climate at all sites is monsoon climate. The annual precipitation rates in Hunan, Jiangxi, Henan and Fujian are $1776,1936,2000$ and $1840 \mathrm{~mm}$, with annual mean temperatures $16.6,16.5,15.2$ and $22.5^{\circ} \mathrm{C}$, respectively. All soils are paddy soil, characterized as stagnant Anthrosols (FAO, 2015).

\section{Experimental design and soil sampling}

The experiments were all started in 2008. The plot size was $20 \mathrm{~m}^{2}(4 \mathrm{~m} \times 5 \mathrm{~m})$, with a completely randomized block design, and repeated each treatment three times. The four treatments were no fertilizer application as control (NF), using milk vetch (Astragalus sinicus L.) as green manure without chemical fertilizer (GM), winter fallow and chemical fertilizer (CF), and a combination of green manure and chemical fertilizer (GMCF). The fertilizer application amounts at each site were referenced to the practices of local farmers (Table 1). The annual incorporation rate of milk vetch at all sites was $22500 \mathrm{~kg} \mathrm{ha}^{-1}$ (fresh biomass). The single rice was grown from May to October or November in Henan and 
Fujian provinces. Hunan and Jiangxi provinces were double-cropping rice, with early rice from April to July and late rice from July to October or November. Milk vetch was sown after single rice or late rice was harvested and incorporated into the soil at their complete bloom stage in March or April of next year (about 15 days before transplanting rice following spring).

The soils were sampled from October to November in 2014 at the four sites after rice was harvested. The collection of soil samples was from five points with $0-20 \mathrm{~cm}$ depth. The soil samples were mixed evenly through a sieve $(<2 \mathrm{~mm})$, and gravel was removed. Parts of fresh samples were stored at $-20^{\circ} \mathrm{C}$ for DNA extraction, and samples for physical and chemical analysis were stored at $4^{\circ} \mathrm{C}$ or air dried.

\section{Grain yield monitoring}

All the grain in each plot was threshed and weighed to calculate the rice yield at the harvest stage. In the double rice cropping areas, the rice yields were calculated as the sum of early rice and late rice yields.

\section{Physical and Chemical analysis of soil samples}

The analysis of soil chemical properties was referred to the methods described by Page (1982), including pH (soil to water ratio of 1:2.5), available potassium (AK) (1.0 $\mathrm{M} \mathrm{CH}_{3} \mathrm{COONH}_{4}$ extraction), available phosphorus (AP) (0.5 M $\mathrm{NaHCO}_{3}$ extraction), $\mathrm{NH}_{4}{ }^{+}-\mathrm{N}$, and $\mathrm{NO}_{3}{ }^{-}-\mathrm{N}(2.0 \mathrm{M} \mathrm{KCl}$ extraction), soil total $\mathrm{N}(\mathrm{TN})$ and soil organic matter (SOM) were determined by kjeldahl nitrogen method and potassium dichromate oxidation method, respectively. The method of measuring soil texture follows Stokes' law. The chemical properties and the soil texture before sowing were listed in Table 2.

\section{Soil DNA extraction and fluorescence quantitative PCR}

The soil DNA extractions were extracted with the FastDNA Spin Kit (MP Bio, Santa Ana, CA, USA), three times for each sample and mixed into one sample. DNA content was quantified with Nanodrop 2000 spectrophotometer (Thermo Fisher Scientific, Waltham, MA, USA).

The quantitative PCRs of the functional genes (nifH, AOA-amoA, AOB-amoA, nirK and nosZ) were performed according to the method described by Gao et al. (2018). Primer information and cycling conditions were given in Table 3.

\section{Statistical analyses}

The SPSS 22.0 was used for statistical analysis. The means of different treatments were analyzed by one-way ANOVA analysis, using the LSD method, and the significance of the difference was compared at the $P<0.05$ level. The correlations among the functional genes involved in $\mathrm{N}$ cycling and soil chemical properties were tested by Pearson's correlation coefficients, and significance was accepted at a probability level of $p<0.05$. The relative influences of various factors on rice yield were evaluated by aggregated boosted trees analysis (ABT), which using "gbmplus" package within R 2.7.1 (De'Ath et al., 2007).

\section{Results}

\section{Yields and soil properties}

The rice yield of each treatment showed a trend of GMCF > CF > GM > NF (Fig. 1). Compared with NF treatment, the rice yields significantly increased in GMCF, CF and GM treatments by $161.2 \%, 130.6 \%$ and $77.2 \%$, respectively. Hunan province had the highest yield, the average yield was $10950 \mathrm{~kg} \mathrm{ha}^{-1}$, followed by Henan, Jiangxi and Fujian provinces 
(average yields of 9483, 9090 and $7904 \mathrm{~kg} \mathrm{ha}^{-1}$, respectively) (Fig. 1). Rice yields significantly increased in GMCF treatment compared with CF treatment in Jiangxi province. The rice yields of GM, CF and GMCF treatments were significantly higher than NF treatment in Henan province.

Soil chemical properties showed various trends under different treatments at the four sites (Table 4). In Hunan province, soil pH was increased in CF and GMCF, compared with NF and GM treatments, and SOM was increased by $\mathrm{GM}$, compared with other treatments. In Jiangxi province, GM treatment significantly increased $\mathrm{NO}_{3}{ }^{-}-\mathrm{N}, \mathrm{compared}^{-}$with other treatments. In Henan province, SOM and TN were increased in GMCF treatment, but pH was reduced compared with $\mathrm{CF}$ treatment. In Fujian province, $\mathrm{NH}_{4}{ }^{+}-\mathrm{N}$ was increased in $\mathrm{CF}$ and $\mathrm{GMCF}$, compared with other treatments. AP was increased by CF and GMCF, compared with NF and GM treatments in Hunan, Jiangxi and Henan provinces (Table 4).

\section{The functional genes involved in $\mathbf{N}$ cycling}

The copy numbers of nifH gene had no significant difference among treatments in Hunan and Fujian provinces. In Jiangxi province, the copies of nifHgene were increased significantly in GMCF, compared with NF treatment. The copies of nifH gene were increased significantly in GMCF, compared with CF and NF treatments in Henan province (Fig. 2A). The abundance of nifH gene varied in different sites (Fig. 2B), Henan province had the highest copy numbers of nifH gene, the average copy number was $3.70 \times 10^{10}$ copies per gram dry soil, followed by Hunan, Fujian and Jiangxi provinces (average numbers of $2.26 \times 10^{10}, 9.19 \times 10^{9}$ and $7.86 \times 10^{9}$ copies per gram dry soil, respectively).

The copy numbers of $A O A-a m o A$ and $A O B-a m o A$ genes had similar trends under different treatments at the four sites (Fig. 3). The copy numbers of AOA-amoA gene increased in CF treatment, compared with NF and GM treatments in Hunan province, and no significant difference was found among treatments of other sites (Fig. 3A). The AOA-amoA abundances were highest in Henan province and lowest in Jiangxi province; no significant difference was found among sites (Fig. 3B). The copy numbers of AOB-amoA gene were increased by CF treatments in Jiangxi province and decreased by GMCF in Fujian province, compared with other treatments (Fig. $3 \mathrm{C}$ ). AOB-amoA gene abundance had no significant difference among sites (Fig. 3D).

The ratios of $A O A$-amoA to $A O B$-amoA gene ranged from 2.70 to 63.25 , indicating that $A O A$-amoA was more abundant than $A O B-a m o A$ in the studied paddy soils. AOA-amoA to AOB-amoA gene ratios were increased by GMCF treatment in Hunan, Jiangxi and Fujian provinces (Fig. 4). The average value of AOA-amoA to AOB-amoA gene ratios varied among sites. Fujian had the highest AOA-amoA to AOB-amoA ratios (22.33), followed by Hunan (18.99), Jiangxi (7.60) and Henan (4.93) provinces (Fig. 4).

The nirK and nos $Z$ genes were selected to reflect the denitrification process. The copy numbers of nirK gene increased in GMCF treatment in Hunan province and increased in CF treatment in Henan and Fujian provinces, compared with NF (Fig. 5A). At the four sites, the nirK gene was more abundant in Henan and Fujian provinces than that in Hunan and Jiangxi provinces (Fig. 5B). The copy numbers of nosZ gene had no difference in Hunan, Henan and Fujian provinces. In Jiangxi province, the application of green manure increased the nos $Z$ gene copies (Fig. 5C). The highest average copy number of nos $Z$ gene among the four sites was found in Henan province, i.e., $7.81 \times 10^{7}$ copies per gram dry soil, and was significantly higher than that in Jiangxi and Fujian provinces $\left(2.97 \times 10^{5}\right.$ and $1.34 \times 10^{7}$ copies per gram dry soil, respectively) (Fig. 5D).

The ratios of nosZ to nirK gene copies ranged from 1.14 to 673.85 , varied a lot among the treatments and sites (Fig. 6). In all the four provinces, the nos $Z$ to nirK ratios were decreased in GMCF treatment, compared with NF. The average value of nos $Z$ to nirk ratio in Hunan province was 503.75, significantly higher than other sites. The average values in Jiangxi, Henan and Fujian provinces were 61.48, 16.08 and 3.47, respectively. 


\section{Correlations among the functional genes involved in $\mathrm{N}$ cycling and soil properties}

Pearson's correlation coefficients were calculated to explore the relationships among the five functional genes involved in $\mathrm{N}$ cycling and the correlations between functional genes and soil properties (Fig. 7). The nirK and nosZ genes in denitrification were positively related to nifH gene and $\mathrm{AOA}-a m o \mathrm{~A}$ and $\mathrm{AOB}-\mathrm{amo} \mathrm{A}$ genes, indicating that denitrification was closely related to $\mathrm{N}$-fixation and nitrification process. The archaeal and bacterial amoA genes had significantly positive correlations with each other, and the same as nirK and nosZ genes (Fig. 7).

The nifH and nosZ genes were negatively correlated with soil $\mathrm{NH}_{4}{ }^{+}-\mathrm{N}$ content, and positively correlated to AK content. The nirk gene in denitrification had significantly negative correlations with soil SOM, TN, $\mathrm{NH}_{4}{ }^{+}-\mathrm{N}, \mathrm{NO}_{3}{ }^{-}{ }^{-} \mathrm{N}$ and $\mathrm{AP}$ content (Fig. 7).

\section{Relative influences of environmental factors on rice yield}

The relative influences of the functional genes and soil chemical properties on rice yield were evaluated based on the aggregated boosted trees analysis (ABT) (Fig. 8). The nirK gene in denitrification was the most crucial factor influencing rice yield, accounting for $63.5 \%$ of the total influence. The nifH gene accounted for $14.1 \%$, and the other three genes together contributed only $22.4 \%$ to rice yield. SOM had the most important factor contributing to rice yield among soil chemical properties, with a contribution rate of $41.0 \%$, followed by $\mathrm{TN}(26.1 \%)$. The contribution of $\mathrm{NH}_{4}{ }^{+} \mathrm{N}$, $\mathrm{AP}, \mathrm{NO}_{3}{ }^{-} \mathrm{N}, \mathrm{AK}$ and $\mathrm{pH}$ to rice yield ranged from $4.9-7.7 \%$.

\section{Discussion}

\section{Effects of green manuring on rice yield, soil nutrients and $\mathrm{N}$ transformation processes}

Milk vetch is a traditional and the most commonly used green manure crop in south China. Application of milk vetch in paddy fields can gain high yields and increase soil nutrient content. The results of multi-site-year joint experiments showed that the combination of milk vetch and chemical fertilizer increased rice yield by 6.53\% (Gao et al., 2020c). After applying green manure, changes in soil environments inevitably caused changes in the composition and activity of soil microbial communities (Zhou et al., 2020; Gao et al., 2021). In this study, the rice yield was increased by green manuring, which was consistent with previous studies. Among the functional genes involved in $\mathrm{N}$ cycling, the nirK gene had the most significant impact on rice yield. For soil chemical properties, SOM and TN were the essential factors that contributed to rice yield. According to the conclusions that the abundance of nirK gene was significantly negatively correlated with soil SOM and TN content, we speculate that while soil SOM and TN content increased, the denitrification process could be inhibited and more inorganic $N$ is absorbed by rice instead of loss through denitrification, which will eventually increase rice yield.

\section{Effects of green manuring on $\mathrm{N}$-fixation}

Previous studies reported that long-term fertilization affects the soil $\mathrm{N}$ cycling process by changing the related structure of microbial communities (Sun et al., 2015), and organic fertilization could promote soil $\mathrm{N}$ cycling by enhancing the abundances of related prokaryotes (Luo et al., 2018). The biological $\mathrm{N}$ fixation ability of legume green manure makes it a compelling alternative source of chemical fertilizers, which reduce the environmental risk of excessive application of $\mathrm{N}$ fertilizer (Xie et al., 2016). By strengthening the connection between plants and soil microorganisms, legume green manure increases the retention of $\mathrm{N}$ in the soil and reduces $\mathrm{N}$ loss (Vries et al., 2012). Among all environmental factors, $\mathrm{C} / \mathrm{N}$, the content and availability of $\mathrm{C}$ and $\mathrm{N}$ were important ones influencing the abundance and community structure of azotobacter (Shu et al., 2012). One of the main ways to induce and stimulate 
the $\mathrm{N}$-fixation activities of microorganisms is to increase the availability of carbon sources and $\mathrm{C} / \mathrm{N}$ ratios. (Bürgmann et al.,2003). In our study, the combination of green manure with chemical fertilizer increased the abundance of nifH gene in Henan and Jiangxi provinces. Previous studies showed that the increase in soil organic carbon content was beneficial in increasing the diversity and abundance of azotobacter (Orr et al., 2012), which was consistent with our results. Abundances of the nifH gene were site specific, with low copy numbers observed in Jiangxi and Fujian provinces (average pH was 4.95 and 4.97, respectively). The nifH gene was most abundant in the neutral to slightly alkaline and less in strongly acidic surface soil sites (Hayden et al., 2010), which was similar to our results. Our study also found that the nifH gene had a significantly negative relationship with soil $\mathrm{NH}_{4}{ }^{+} \mathrm{N}$. The addition of inorganic $\mathrm{N}$ will inhibit the rate of biological $\mathrm{N}$ fixation (Yang et al.,2021), which means that when the soil $\mathrm{N}$ content was too high, the ability of azotobacter will be suppressed.

\section{Effects of green manure on soil nitrification and denitrification}

The abundance and community of $A O A-a m o A$ and $A O B-a m o A$ genes were influenced by complex factors in agricultural soils (Zeglin et al., 2011; Hu et al., 2014; Huang et al., 2014; Ouyang et al., 2016). Soil pH was one of the most important factors that influence the characteristics of ammonia oxidizers (Hu et al., 2013; Stempfhuber et al., 2015). In our study, AOA-amoA gene copies were predominant in all four sites, which was consistent with former studies (Huang et al., 2014; Li et al., 2015; Ouyang et al., 2016). The AOA-amoA to AOB-amoA rations were the largest in Fujian province, which might be due to its lowest $\mathrm{pH}$ value. AOA had a competitive advantage over $A O B$ in acidic soils, and in acidic or neutral soil, the lower $\mathrm{pH}$ value might suggest a higher AOA-amoA to AOB-amoA ratio (Hu et al., 2013; Hu et al., 2014; Che et al., 2015). Previous studies found that in acid soils, the contribution rate of AOA to soil nitrification was significantly higher than that of AOB (He et al., 2012). In our study, AOA-amoA to AOB-amoA ratios were increased in GMCF treatment in acid soils. However, in Hunan province, the alkaline paddy soil also had a relative higher $\mathrm{AOA}-a m o A$ to $\mathrm{AOB}-\mathrm{amoA}$ ratio in $\mathrm{GMCF}$, indicating other factors that affect the relative abundance of $\mathrm{AOA}$ and $A O B$, except for $\mathrm{pH}$. Related research showed that $A O A$ could directly use organic carbon for mixed vegetative growth (Ingalls et al.,2006), and soil SOM in Hunan province was higher than other sites, which may confirm this view.

Nitrification and denitrification are closely related, and the analysis of functional genes involved in the denitrification process reveals the relationship between the soil environment and the denitrification microbial community (Levy-Booth et al., 2014; Cui et al., 2016). In our study, AOA-amoA and AOB-amoA genes involved in the nitrification process had significantly positive correlations with nirK and nos $Z$ genes involved in the denitrification process. For the denitrification process, both green manure and chemical fertilizer increased the abundance of nirk gene in Fujian province, while the abundance of nos $Z$ gene was decreased by the combination of green manure and chemical fertilizer in Jiangxi province. Previous studies found that the activities of ammonia oxidizers and nitrite oxidizers were mainly determined by soil type and physicochemical properties (Wang et al., 2015). The nirK and nos $Z$ genes varied among different treatments in our study, i.e., highest in Henan and lowest in Jiangxi. The differences in soil type, physicochemical properties and climate may be the reasons for these differences.

In our study, the average ratios of nosZ to nirK gene copies in four sites ranged from 3.47 to 503.75 , which showed that $n o s Z$ gene played a leading role in the denitrification process in rice fields. The nos $Z$ gene had a significantly negative correlation with soil $\mathrm{NH}_{4}{ }^{+}-\mathrm{N}$ content. It showed that the combination of green manure and chemical fertilizer with the highest $\mathrm{NH}_{4}{ }^{+}-\mathrm{N}$ content would weaken the denitrification process in the soil, thereby reducing the emission of $\mathrm{N}$-containing greenhouse gases. Levy-Booth et al. (2014) found that $\mathrm{N}_{2} \mathrm{O}$ emissions were related to the nitrifying and denitrifying communities by quantifying genes involved in the $\mathrm{N}$ cycling. The higher nosZ/nirK ratio, the higher the proportion of $\mathrm{N}_{2} \mathrm{O}$ being reduced to $\mathrm{N}_{2}$ (Kandeler et al., 2009). We found that Hunan province had the highest nosZ/nirK ratio, suggesting that the higher capability of transforming the greenhouse gas $\mathrm{N}_{2} \mathrm{O}$ into $\mathrm{N}_{2}$ in Hunan 
province. Unlike other provinces, the typical alkaline paddy soil in Hunan province had unique characteristics, resulting in different responses to green manuring. The mechanisms under the changes of functional genes need further investigation.

\section{Conclusions}

The multi-site studies based on the long-term experiments in south China conclude that the combined application of green manure and chemical fertilizers significantly increased rice yields. The copies of nifH gene in Henan and Jiangxi provinces were increased. The combination of green manure and chemical fertilizer inhibited the nitrification and denitrification process. Soil SOM, TN and nirK genes were the main factors affecting rice yield in the rice-green manure cropping systems.

\section{Declarations}

\section{Funding}

This work was supported by China Agriculture Research System of MOF and MARA (CARS-22); and National Natural Science Foundation of China (42007071).

\section{Conflicts of interest}

The authors declare that they have no known competing financial interests or personal relationships that could have appeared to influence the work reported in this paper.

\section{Availability of data and material}

The datasets used or analyzed during the current study are available from the corresponding author on reasonable request.

\section{Code availability}

The code used during the current study are available from the corresponding author on reasonable request.

\section{Acknowledgements}

This work was supported by China Agriculture Research System of MOF and MARA (CARS-22); and National Natural Science Foundation of China (42007071).

\section{References}

1. Bothe H, Gunter J, Schloter M, Ward BB, Witzel K-P (2000) Mocular analysis of ammonia oxidation and denitrification in natural environments. FEMS Microbiol Ecol 24:673-690

2. Burgmann H, Widmer F, Sigler WV, Zeyer J (2003) Mrna extraction and reverse transcription-pcr protocol for detection of nifh gene expression by azotobacter vinelandii in soil. Appl Environ Microbiol 69(4):1928-1935

3. Che J, Zhao XQ, Zhou X, Jia ZJ, Shen RF (2015) High pH-enhanced soil nitrification was associated with ammonia-oxidizing bacteria rather than archaea in acidic soils. Appl Soil Ecol 85:21-29

4. Chen X, Zhang L-M, Shen J-P, Xu Z, He J-Z (2010) Soil type determines the abundance and community structure of ammonia-oxidizing bacteria and archaea in flooded paddy soils. J Soils Sediments 10:1510-1516 
5. Cui P, Fan F, Yin C, Song A, Huang P, Tang Y, Zhu P, Peng C, Li T, Wakelin SA, Liang Y (2016) Long-term organic and inorganic fertilization alters temperature sensitivity of potential N2O emissions and associated microbes. Soil Biol Biochem 93:131-141

6. De' Ath G. (2007) Boosted Trees for Ecological Modeling and Prediction. Ecology, 88(1):243-251

7. Ding K, Zhong L, Xin XP, Xu ZH, Kang XM, Liu WJ, Rui YC, Jiang LL, Tang L, Wang YF (2014) Effect of grazing on the abundance of functional genes associated with $\mathrm{N}$ cycling in three types of grassland in Inner Mongolia. $J$ Soils Sediments 15:683-693

8. Fan K, Delgado-Baquerizo M, Guo X, Wang D, Chu H (2019) Suppressed n fixation and diazotrophs after four decades of fertilization. Microbiome, 7(1)

9. Fan K, Weisenhorn P, Gilbert JA, Shi Y, Bai Y, Chu H (2018) Soil ph correlates with the co-occurrence and assemblage process of diazotrophic communities in rhizosphere and bulk soils of wheat fields. Soil Biol Biochem 121:185-192

10. FAO (2015) World reference base for soil resources 2014: International soil classification system for naming soils and creating legends for soil maps. Update 2015. World Soil Resour. Rep. 106. FAO, Rome, Italy

11. Gao SJ, Zhou GP, Liao YL, Lu YH, Nie J, Cao WD (2020a) Contributions of ammonia-oxidising bacteria and archaea to nitrification under long-term application of green manure in alkaline paddy soil. Geoderma 374:114419

12. Gao SJ, Zhou GP, Rees RM, Cao WD (2020b) Green manuring inhibits nitrification in a typical paddy soil by changing the contributions of ammonia-oxidizing archaea and bacteria. Appl Soil Ecol 156:103698

13. Gao SJ, Zhou GP, Cao WD (2020c) Effects of milk vetch (Astragalus sinicus) as winter green manure on rice yield and rate of fertilizer application in rice paddies in south China (in Chinese). Journal of Plant Nutrition Fertilizers 26(12):2115-2126

14. Gao SJ, Cao WD, Zhou GP, Rees RM (2021) Bacterial communities in paddy soils changed by milk vetch as green manure: a study conducted across six provinces in south China. Pedosphere 31(4):521-530

15. Gao SJ, Cao WD, Zou CQ, Gao JS, Huang J, Bai JS, Zeng NH, Shimizu K, Wright a, Dou FG (2018) Ammoniaoxidizing archaea are more sensitive than ammonia-oxidizing bacteria to long-term application of green manure in red paddy soil. Applied Soil Ecology, 124(5)

16. Hayden HL, Drake J, Imhof M, Oxley APA, Norng S, Mele PM (2010) The abundance of nitrogen cycle genes amoa and nifh depends on land-uses and soil types in south-eastern australia. Soil Biol Biochem 42(10):1774-1783

17. He JZ, Hu HW, Zhang LM (2012) Current insights into the autotrophic thaumarchaeal ammonia oxidation in acidic soils. Soil Biol Biochem 55(6):146-154

18. Hu XJ, Liu JJ, Zhu P, Wei D, Jin J, Liu XB, Wang G-h (2018) Long-term manure addition reduces diversity and changes community structure of diazotrophs in a neutral black soil of northeast China. Journal of Soils and Sediments

19. Hu B, Liu S, Wang W, Shen L, Lou L, Liu W, Tian G, Xu X, Zheng P (2014) pH-dominated niche segregation of ammonia-oxidising microorganisms in Chinese agricultural soils. FEMS Microbiol Ecol 90:290-299

20. Hu HW, Zhang LM, Dai Y, Di HJ, He JZ (2013) pH-dependent distribution of soil ammonia oxidizers across a large geographical scale as revealed by high-throughput pyrosequencing. J Soils Sediments 13:1439-1449

21. Huang L, Dong H, Wang S, Huang Q, Jiang H (2014) Diversity and Abundance of Ammonia-Oxidizing Archaea and Bacteria in Diverse Chinese Paddy Soils. Geomicrobiol J 31:12-22

22. Ingalls A, Shah S, Hansman R, Aluwihare L, Santos G, Druffel E, Pearson A (2006) Quantifying archaeal community autotrophy in the mesopelagic ocean using natural radiocarbon. Proc Natl Acad Sci USA 103(17):6442-6447 
23. Ishii S, Ikeda S, Minamisawa K, Senoo K (2011) Nitrogen Cycling in Rice Paddy Environments: Past Achievements and Future Challenges. Microbes Environments 26:282-292

24. Kandeler E, Brune T, Enowashu E, Dorr N, Guggenberger G, Lamersdorf N, Philippot L (2009) Response of total and nitrate-dissimilating bacteria to reduced $\mathrm{N}$ deposition in a spruce forest soil profile. FEMS Microbiol Ecol 67:444454

25. Leininger S, Urich T, Schloter M, Schwark L, Qi J, Nicol GW, Prosser JI, Schuster SC, Schleper C (2006) Archaea predominate among ammonia-oxidizing prokaryotes in soils. Nature 442:806-809

26. Levy-Booth DJ, Prescott CE, Grayston SJ (2014) Microbial functional genes involved in nitrogen fixation, nitrification and denitrification in forest ecosystems. Soil Biol Biochem 75:11-25

27. Li H, Weng BS, Huang FY, Su JQ, Yang XR (2015) pH regulates ammonia-oxidizing bacteria and archaea in paddy soils in Southern China. q 99, 6113-6123

28. Liang H, Gao SJ, Qi ZM, Hu KL, Xu JZ (2021) Leaching loss of dissolved organic nitrogen from cropland ecosystems. Environmental Reviews. https://doi.org/10.1139/er-2020-0059

29. Liu H, Li J, Zhao Y, Xie K, Tang X, Wang S, Li Z, Liao Y, Xu J, Di H (2018) Ammonia oxidizers and nitrite-oxidizing bacteria respond differently to long-term manure application in four paddy soils of south of China. Sci Total Environ 633:641-648

30. Luo G, Friman Vp, Chen H, Liu M, Wang M, Guo S, Ling N, Shen Q (2018) Long-term fertilization regimes drive the abundance and composition of $\mathrm{N}$-cycling-related prokaryotic groups via soil particle-size differentiation. Soil Biol Biochem 116:213-223

31. Lupwayi NZ, Soon YK, Yang XM (2016) Soil microbial properties during decomposition of pulse crop and legume green manure residues in three consecutive subsequent crops. Canadian Journal of Soil Science, 1-14

32. Macguidwin AE, Knuteson DL, Connell T, Bland WL, Bartelt KD (2012) Manipulating inoculum densities of Verticillium dahliae and Pratylenchus penetrans with green manure amendments and solarization influence potato yield. Phytopathology 102:519-527

33. Martens-Habbena W, Berube PM, Urakawa H, Torre JRDL, Stahl DA (2009) Ammonia oxidation kinetics determine niche separation of nitrifying archaea and bacteria. Nature 461(7266):976-979

34. Mcneill AM, Fillery IRP (2008) Field measurement of lupin belowground nitrogen accumulation and recovery in the subsequent cereal-soil system in a semi-arid mediterranean-type climate. Plant Soil 302(s1-2):297-316

35. Montoya M, Guardia G, Huetos JR, Hinojosa AC, Vallejo A (2021) Zinc-nitrogen co-fertilization influences $\mathrm{N}_{2} \mathrm{O}$ emissions and microbial communities in an irrigated maize field. Geoderma, 383

36. Orr CH, Carlo L, Cummings SP, Cooper JM, Mark IA (2012) Impacts of organic and conventional crop management on diversity and activity of free-living nitrogen fixing bacteria and total bacteria are subsidiary to temporal effects. PLoS ONE 7(12):e52891-

37. Ouyang Y, Norton JM, Stark JM, Reeve JR, Habteselassie MY (2016) Ammonia-oxidizing bacteria are more responsive than archaea to nitrogen source in an agricultural soil. Soil Biol Biochem 96:4-15

38. Page AL, Miller RH, Dennis K, R (1982) Methods of soil analysis. Catena 15(1):99-100

39. Poly F, Monrozier LJ, Bally R (2001) Improvement in the RFLP procedure for studying the diversity of nifH genes in communities of nitrogen fixers in soil. Research in microbiology 152:95-103

40. Prosser JI, Nicol GW (2012) Archaeal and bacterial ammonia-oxidisers in soil: the quest for niche specialisation and differentiation. Trends Microbiol 20:523-531

41. Qin HL, Wang D, Xing XY, Tang YF, Wei XM, Chen XB, Zhang WZ, Chen AL, Li LL, Liu Y, Zhu BL (2021) A few key nirk- and nosz-denitrifier taxa play a dominant role in moisture-enhanced n2o emissions in acidic paddy soil. 
Geoderma 385(10):114917

42. Rosch C, Mergel A, Bothe H (2002) Biodiversity of Denitrifying and Dinitrogen-Fixing Bacteria in an Acid Forest Soil. Appl Environ Microbiol 68:3818-3829

43. Sharifi M, Lynch DH, Hammermeister A, Burton DL, Messiga AJ (2014) Effect of green manure and supplemental fertility amendments on selected soil quality parameters in an organic potato rotation in eastern canada. Nutr Cycl Agroecosyst 100(2):135-146

44. Shu W, Pablo GP, Jun Y, Danfeng H (2012) Abundance and diversity of nitrogen-fixing bacteria in rhizosphere and bulk paddy soil under different duration of organic management. World J Microbiol Biotechnol 28:493-503

45. Stempfhuber B, Engel M, Fischer D, Neskovic-Prit G, Wubet T, Schoning I, Gubry-Rangin C, Kublik S, Schloter-Hai B, Rattei T, Welzl G, Nicol GW, Schrumpf M, Buscot F, Prosser JI, Schloter M (2015) pH as a Driver for AmmoniaOxidizing Archaea in Forest Soils. Microbial ecology 69:879-883

46. Sun R, Guo X, Wang D, Chu H (2015) Effects of long-term application of chemical and organic fertilizers on the abundance of microbial communities involved in the nitrogen cycle. Appl Soil Ecol 95:171-178

47. Tejada M, Gonzalez JL, Garcia-Martinez AM, Parrado J (2008) Effects of different green manures on soil biological properties and maize yield. Bioresour Technol 99:1758-1767

48. Vries FTD, Bardgett RD (2012) Plant-microbial linkages and ecosystem nitrogen retention: lessons for sustainable agriculture. Front Ecol Environ 10(8):425-432

49. Wang B, Zhao J, Guo Z, Ma J, Xu H, Jia Z (2015) Differential contributions of ammonia oxidizers and nitrite oxidizers to nitrification in four paddy soils. ISME J 9:1062-1075

50. Xie Z, Tu S, Shah F, Xu C, Chen J, Han D, Liu G, Li H, Muhammad I, Cao W (2016) Substitution of fertilizer-N by green manure improves the sustainability of yield in double-rice cropping system in south China. Field Crops Research 188:142-149

51. Yang L, Bai JS, Liu J, Zeng NH, Cao WD (2018a) Green manuring effect on changes of soil nitrogen fractions, maize growth, and nutrient uptake. Agronomy, 8(11)

52. Yang O, Evans SE, Friesen ML, Tiemann LK (2018b) Effect of nitrogen fertilization on the abundance of nitrogen cycling genes in agricultural soils: a meta-analysis of field studies. Soil Biol Biochem 127:S0038071718302864-

53. Yang L, Bai JS, Zeng NH, Zhou X, Liao YL, Lu YH, Robert MRees, Nie J, Cao WD (2019) Diazotroph abundance and community structure are reshaped by straw return and mineral fertilizer in rice-rice-green manure rotation. Appl Soil Ecol 136:11-20

54. Zeglin LH, Taylor AE, Myrold DD, Bottomley PJ (2011) Bacterial and archaeal amoA gene distribution covaries with soil nitrification properties across a range of land uses. Environmental microbiology reports 3:717-726

55. Zhou GP, Gao SJ, Lu YH, Liao YL, Cao NJ, W.D (2020) Co-incorporation of green manure and rice straw improves rice production, soil chemical, biochemical and microbiological properties in a typical paddy field in southern china. Soil and Tillage Research, 197

\section{Tables}


Table 1

Fertilizer application rates for the four locations

\begin{tabular}{|c|c|c|c|c|}
\hline Site & Rice type & $\mathbf{N}\left(\mathrm{kg} \mathrm{ha}^{-1}\right)$ & $\mathrm{P}_{2} \mathrm{O}_{5}\left(\mathrm{~kg} \mathrm{ha}^{-1}\right)$ & $\mathrm{K}_{2} \mathrm{O}\left(\mathrm{kg} \mathrm{ha}^{-1}\right)$ \\
\hline \multirow[t]{2}{*}{ Hunan } & Early rice & 150 & 75 & 90 \\
\hline & Late rice & 180 & 45 & 120 \\
\hline \multirow[t]{2}{*}{ Jiangxi } & Early rice & 150 & 75 & 120 \\
\hline & Late rice & 180 & 75 & 150 \\
\hline Henan & Single rice & 225 & 135 & 135 \\
\hline Fujian & Single rice & 135 & 54 & 94.5 \\
\hline
\end{tabular}

Table 2

Soil physical and chemical properties at the four sites before sowing

\begin{tabular}{|lllllllll|}
\hline Site & $\mathbf{p H}$ & $\begin{array}{l}\text { SOM }\left(\mathbf{g ~ k g}^{-}\right. \\
\mathbf{1})\end{array}$ & $\begin{array}{l}\mathrm{TN}\left(\mathbf{g ~ k g}^{-}\right. \\
\mathbf{1})\end{array}$ & $\begin{array}{l}\mathbf{A P}(\mathbf{m g ~ k g} \\
\mathbf{1})\end{array}$ & $\begin{array}{l}\mathbf{A K}(\mathbf{m g ~ k g} \\
\mathbf{1})\end{array}$ & $\begin{array}{l}\text { Clay } \\
(\%)\end{array}$ & Silt (\%) & Sand (\%) \\
\hline Hunan & 7.92 & 53.0 & 3.54 & 23.2 & 93.1 & 8.5 & 29.4 & 62.0 \\
\hline Jiangxi & 4.65 & 33.8 & 2.57 & 4.8 & 51.0 & 4.8 & 38.1 & 57.1 \\
\hline Henan & 6.80 & 21.4 & 1.55 & 10.2 & 100.6 & 6.4 & 33.3 & 60.2 \\
\hline Fujian & 4.93 & 22.6 & 1.23 & 26.2 & 43.7 & 19.4 & 34.1 & 46.5 \\
\hline
\end{tabular}

Clay, silt and sand is determined as particles $<2 \mu \mathrm{m}, 2 \mu \mathrm{m}-0.05 \mathrm{~mm}$, and 0.05-2mm, respectively 
Table 3

Primers and conditions for quantitative PCR of the functional genes involved in $\mathrm{N}$ cycling

\begin{tabular}{|c|c|c|c|c|c|}
\hline $\begin{array}{l}\text { Target } \\
\text { group }\end{array}$ & Primer & Sequence $\left(5^{\prime}-3^{\prime}\right)$ & $\begin{array}{l}\text { Amplicon } \\
\text { length } \\
\text { (bp) }\end{array}$ & $\begin{array}{l}\text { Cycling } \\
\text { conditions }\end{array}$ & Reference \\
\hline nifH & nifH-F/nifH-R & $\begin{array}{l}\text { AAAGGYGGWATCGGYAARTCCACCAC/ } \\
\text { TTGTTSGCSGCRTACATSGCCATCAT }\end{array}$ & 450 & $\begin{array}{l}5 \text { min at } 95^{\circ} \mathrm{C} \\
\text { followed by } 40 \\
\text { cycles of } 5 \mathrm{~s} \text { at } \\
95^{\circ} \mathrm{C}, 30 \mathrm{~s} \text { at } 57^{\circ} \mathrm{C} \text {, } \\
\text { and } 40 \mathrm{~s} \text { at } 72^{\circ} \mathrm{C}\end{array}$ & $\begin{array}{l}\text { (Rosch et } \\
\text { al., 2002) }\end{array}$ \\
\hline $\begin{array}{l}\text { AOA } \\
- \\
\text { amoA }\end{array}$ & $\begin{array}{l}\text { Arch- } \\
\text { amoAF/Arch- } \\
\text { amoAR }\end{array}$ & $\begin{array}{l}\text { STAATGGTCTGGCTTAGACG/ } \\
\text { GCGGCCATCCATCTGTATGT }\end{array}$ & 635 & $\begin{array}{l}5 \text { min at } 95^{\circ} \mathrm{C} \\
\text { followed by } 40 \\
\text { cycles of } 5 \mathrm{~s} \text { at } \\
95^{\circ} \mathrm{C}, 30 \mathrm{~s} \text { at } 56^{\circ} \mathrm{C} \text {, } \\
\text { and } 40 \mathrm{~s} \text { at } 72^{\circ} \mathrm{C}\end{array}$ & $\begin{array}{l}\text { (Francis et } \\
\text { al., 2005) }\end{array}$ \\
\hline $\begin{array}{l}\text { AOB } \\
- \\
\text { amoA }\end{array}$ & $\begin{array}{l}\text { amoA- } \\
\text { 1F/amoA-2R }\end{array}$ & $\begin{array}{l}\text { GGGGTTTCTACTGGTGGT/ } \\
\text { CCCCTCKGSAAAGCCTTCTTC }\end{array}$ & 491 & $\begin{array}{l}5 \text { min at } 95^{\circ} \mathrm{C} \\
\text { followed by } 40 \\
\text { cycles of } 5 \text { s at } \\
95^{\circ} \mathrm{C}, 30 \text { s at } 56^{\circ} \mathrm{C} \text {, } \\
\text { and } 40 \text { s at } 72^{\circ} \mathrm{C}\end{array}$ & $\begin{array}{l}\text { (Rotthauwe } \\
\text { et al., } \\
1997 \text { ) }\end{array}$ \\
\hline nirk & $\mathrm{FlaCu} / \mathrm{R} 3 \mathrm{Cu}$ & $\begin{array}{l}\text { ATCATGGTSCTGCCGCG/ } \\
\text { GCCTCGATCAG(A/G)TTGTGGTT }\end{array}$ & 450 & $\begin{array}{l}5 \text { min at } 95^{\circ} \mathrm{C} \\
\text { followed by } 40 \\
\text { cycles of } 5 \text { s at } \\
95^{\circ} \mathrm{C}, 30 \text { s at } 56^{\circ} \mathrm{C} \text {, } \\
\text { and } 40 \text { s at } 72^{\circ} \mathrm{C}\end{array}$ & $\begin{array}{l}\text { (Levy- } \\
\text { Booth et } \\
\text { al., 2014) }\end{array}$ \\
\hline nosZ & $\begin{array}{l}\text { NosZ2F/ } \\
\text { NosZ2R }\end{array}$ & $\begin{array}{l}\text { CGCRACGGCAASAAGGTSMSSGT/ } \\
\text { CAKRTGCAKSGCRTGGCAGAA }\end{array}$ & 268 & $\begin{array}{l}5 \text { min at } 95^{\circ} \mathrm{C} \\
\text { followed by } 40 \\
\text { cycles of } 5 \mathrm{~s} \text { at } \\
95^{\circ} \mathrm{C}, 30 \text { s at } 57^{\circ} \mathrm{C} \text {, } \\
\text { and } 40 \text { s at } 72^{\circ} \mathrm{C}\end{array}$ & $\begin{array}{l}\text { (Kandeler } \\
\text { et al., } \\
\text { 2009) }\end{array}$ \\
\hline
\end{tabular}

Table 4 Soil chemical properties at the four sites 


\begin{tabular}{|c|c|c|c|c|c|c|c|}
\hline Treatment & $\mathrm{pH}$ & $\operatorname{SOM}\left(\mathrm{g} \mathrm{kg}^{-1}\right)$ & $\mathrm{TN}\left(\mathrm{g} \mathrm{kg}^{-1}\right)$ & $\begin{array}{l}\mathrm{NH}_{4}^{+}-\mathrm{N} \\
\left(\mathrm{mg} \mathrm{kg}^{-1}\right)\end{array}$ & $\begin{array}{l}\mathrm{NO}_{3}^{-}-\mathrm{N} \\
\left(\mathrm{mg} \mathrm{kg}^{-1}\right)\end{array}$ & $\begin{array}{l}\mathrm{AP}(\mathrm{mg} \\
\left.\mathrm{kg}^{-1}\right)\end{array}$ & $\begin{array}{l}\text { AK (mg } \\
\left.\mathrm{kg}^{-1}\right)\end{array}$ \\
\hline \multicolumn{8}{|l|}{ Hunan } \\
\hline NF & $7.38 \pm 0.08 b$ & $50.84 \pm 0.88 b$ & $2.76 \pm 0.20 \mathrm{a}$ & $0.57 \pm 0.09 a$ & $13.64 \pm 1.15 a$ & $\begin{array}{l}18.1 \pm 1.7 \\
b\end{array}$ & $\begin{array}{l}104.0 \pm 3.0 \\
a b\end{array}$ \\
\hline GM & $7.41 \pm 0.01 b$ & $56.67 \pm 0.75 a$ & $3.17 \pm 0.06 a$ & $0.60 \pm 0.23 a$ & $14.95 \pm 2.50 \mathrm{a}$ & $\begin{array}{l}20.3 \pm 0.3 \\
b\end{array}$ & $\begin{array}{l}99.0 \pm 1.0 \\
b\end{array}$ \\
\hline $\mathrm{CF}$ & $7.61 \pm 0.03 a$ & $48.41 \pm 1.71 b$ & $2.88 \pm 0.04 a$ & $0.74 \pm 0.14 a$ & $16.23 \pm 1.25 a$ & $\begin{array}{l}43.8 \pm 2.4 \\
a\end{array}$ & $\begin{array}{l}109.3 \pm 4.0 \\
\mathrm{ab}\end{array}$ \\
\hline GMCF & $7.62 \pm 0.02 a$ & $46.52 \pm 1.38 b$ & $2.88 \pm 0.09 a$ & $0.74 \pm 0.22 a$ & $19.30 \pm 3.02 \mathrm{a}$ & $\begin{array}{l}37.6 \pm 2.3 \\
a\end{array}$ & $\begin{array}{l}116.4 \pm 4.4 \\
\mathrm{a}\end{array}$ \\
\hline \multicolumn{8}{|l|}{ Jiangxi } \\
\hline NF & $5.21 \pm 0.12 a$ & $33.36 \pm 0.49 a$ & $1.82 \pm 0.08 a$ & $18.00 \pm 2.46 a$ & $6.76 \pm 1.72 b$ & $\begin{array}{l}9.2 \pm 0.9 \\
c\end{array}$ & $\begin{array}{l}40.4 \pm 1.3 \\
b\end{array}$ \\
\hline GM & $4.87 \pm 0.11 a$ & $40.58 \pm 1.61 a$ & $2.14 \pm 0.19 a$ & $16.33 \pm 1.38 a$ & $17.71 \pm 1.57 \mathrm{a}$ & $\begin{array}{l}26.9 \pm 0.3 \\
b\end{array}$ & $\begin{array}{l}78.4 \pm 8.6 \\
a\end{array}$ \\
\hline $\mathrm{CF}$ & $4.85 \pm 0.10 a$ & $34.21 \pm 3.11 a$ & $1.95 \pm 0.17 a$ & $15.28 \pm 1.24 a$ & $10.76 \pm 0.35 b$ & $\begin{array}{l}41.1 \pm 1.9 \\
\text { a }\end{array}$ & $\begin{array}{l}56.9 \pm 10.1 \\
a b\end{array}$ \\
\hline GMCF & $4.87 \pm 0.06 a$ & $36.26 \pm 1.73 a$ & $2.06 \pm 0.12 a$ & $18.94 \pm 1.13 a$ & $11.99 \pm 1.90 b$ & $\begin{array}{l}41.8 \pm 2.0 \\
a\end{array}$ & $\begin{array}{l}74.2 \pm 17.0 \\
\mathrm{ab}\end{array}$ \\
\hline \multicolumn{8}{|l|}{ Henan } \\
\hline NF & $6.15 \pm 0.16 a$ & $22.63 \pm 1.31 c$ & $1.23 \pm 0.06 b$ & $0.86 \pm 0.23 b$ & $3.04 \pm 0.40 b$ & $\begin{array}{l}7.2 \pm 0.6 \\
b\end{array}$ & $\begin{array}{l}93.6 \pm 2.1 \\
a\end{array}$ \\
\hline GM & $5.09 \pm 0.04 b$ & $26.15 \pm 0.69 a b$ & $1.43 \pm 0.03 a$ & $1.39 \pm 0.28 a b$ & $6.15 \pm 0.66 a b$ & $\begin{array}{l}8.2 \pm 0.8 \\
b\end{array}$ & $\begin{array}{l}85.9 \pm 3.8 \\
a\end{array}$ \\
\hline CF & $6.13 \pm 0.01 a$ & $23.69 \pm 1.18 \mathrm{bc}$ & $1.23 \pm 0.05 b$ & $1.15 \pm 0.10 a b$ & $4.64 \pm 1.90 \mathrm{ab}$ & $\begin{array}{l}14.6 \pm 2.9 \\
\text { a }\end{array}$ & $\begin{array}{l}97.0 \pm 3.6 \\
a\end{array}$ \\
\hline GMCF & $5.16 \pm 0.07 b$ & $28.35 \pm 0.47 a$ & $1.49 \pm 0.04 a$ & $1.81 \pm 0.19 a$ & $12.36 \pm 4.53 a$ & $\begin{array}{l}16.5 \pm 0.8 \\
a\end{array}$ & $\begin{array}{l}88.2 \pm 3.1 \\
a\end{array}$ \\
\hline \multicolumn{8}{|l|}{ Fujian } \\
\hline NF & $4.99 \pm 0.21 a$ & $21.35 \pm 1.77 a$ & $1.19 \pm 0.13 a$ & $0.52 \pm 0.25 b$ & $2.17 \pm 0.37 a$ & $\begin{array}{l}15.0 \pm 1.5 \\
\text { a }\end{array}$ & $\begin{array}{l}26.4 \pm 4.9 \\
a\end{array}$ \\
\hline GM & $4.92 \pm 0.11 a$ & $22.05 \pm 0.97 a$ & $1.20 \pm 0.07 a$ & $0.56 \pm 0.12 b$ & $3.40 \pm 0.82 a$ & $\begin{array}{l}12.4 \pm 4.4 \\
\text { a }\end{array}$ & $\begin{array}{l}32.5 \pm 6.7 \\
a\end{array}$ \\
\hline CF & $4.97 \pm 0.15 a$ & $21.73 \pm 0.51 a$ & $1.10 \pm 0.02 \mathrm{a}$ & $1.53 \pm 0.15 a$ & $2.41 \pm 0.09 a$ & $\begin{array}{l}19.3 \pm 1.4 \\
\mathrm{a}\end{array}$ & $\begin{array}{l}27.7 \pm 3.7 \\
a\end{array}$ \\
\hline GMCF & $4.99 \pm 0.06 a$ & $23.54 \pm 0.76 a$ & $1.13 \pm 0.04 a$ & $1.20 \pm 0.05 a$ & $2.06 \pm 0.22 a$ & $\begin{array}{l}17.9 \pm 1.1 \\
a\end{array}$ & $\begin{array}{l}31.8 \pm 0.8 \\
a\end{array}$ \\
\hline
\end{tabular}

Values in the table are means $\pm S E(n=3)$. The different letters after the values represent significant differences in different treatments under the same index at the same site 

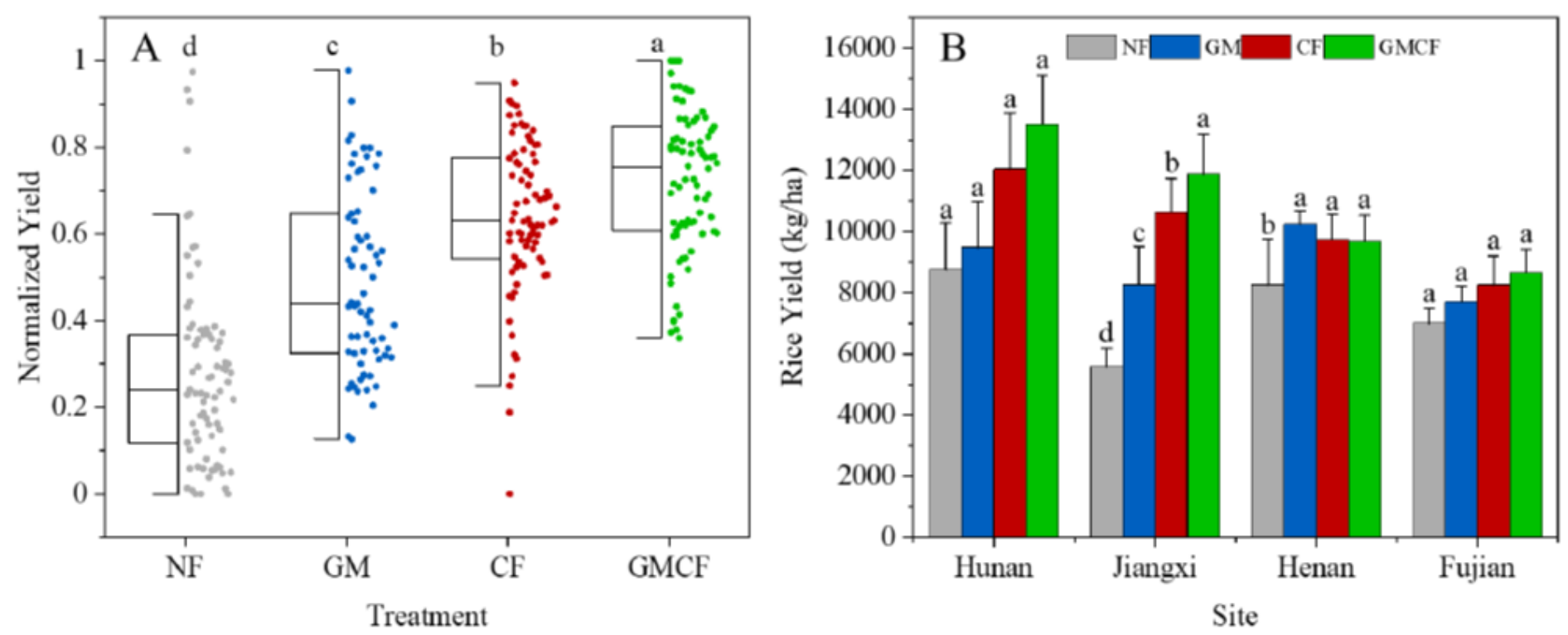

Figure 1

The overall trends of rice yield after normalization under four treatments $(A)$, and rice yields under different treatments at four sites (B). Vertical T bars in the Box-plot indicate maximum and minimum, respectively, circles represent samples. Vertical T bars in the histogram indicate SE. Different letters indicate significant differences among treatments $(\mathrm{P}<0.05)$
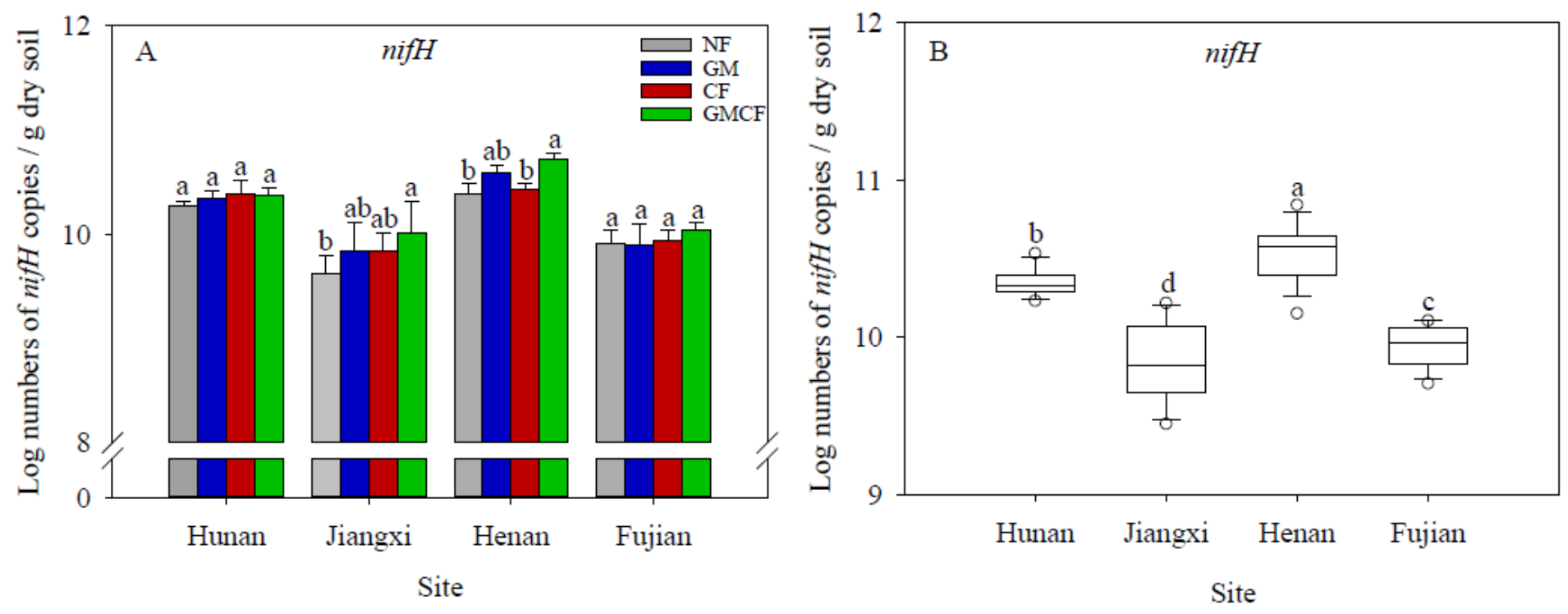

\section{Figure 2}

The abundance of nifH gene in paddy soil under different treatments at the four sites $(\mathrm{A})$, and the overall trends of the nifH gene abundance at the four sites (B). Vertical T bars in the histogram indicate SE. Vertical T bars in the Box-plot indicate maximum and minimum, respectively; circles represent outliers. Different letters indicate significant differences $(P<0.05)$ 

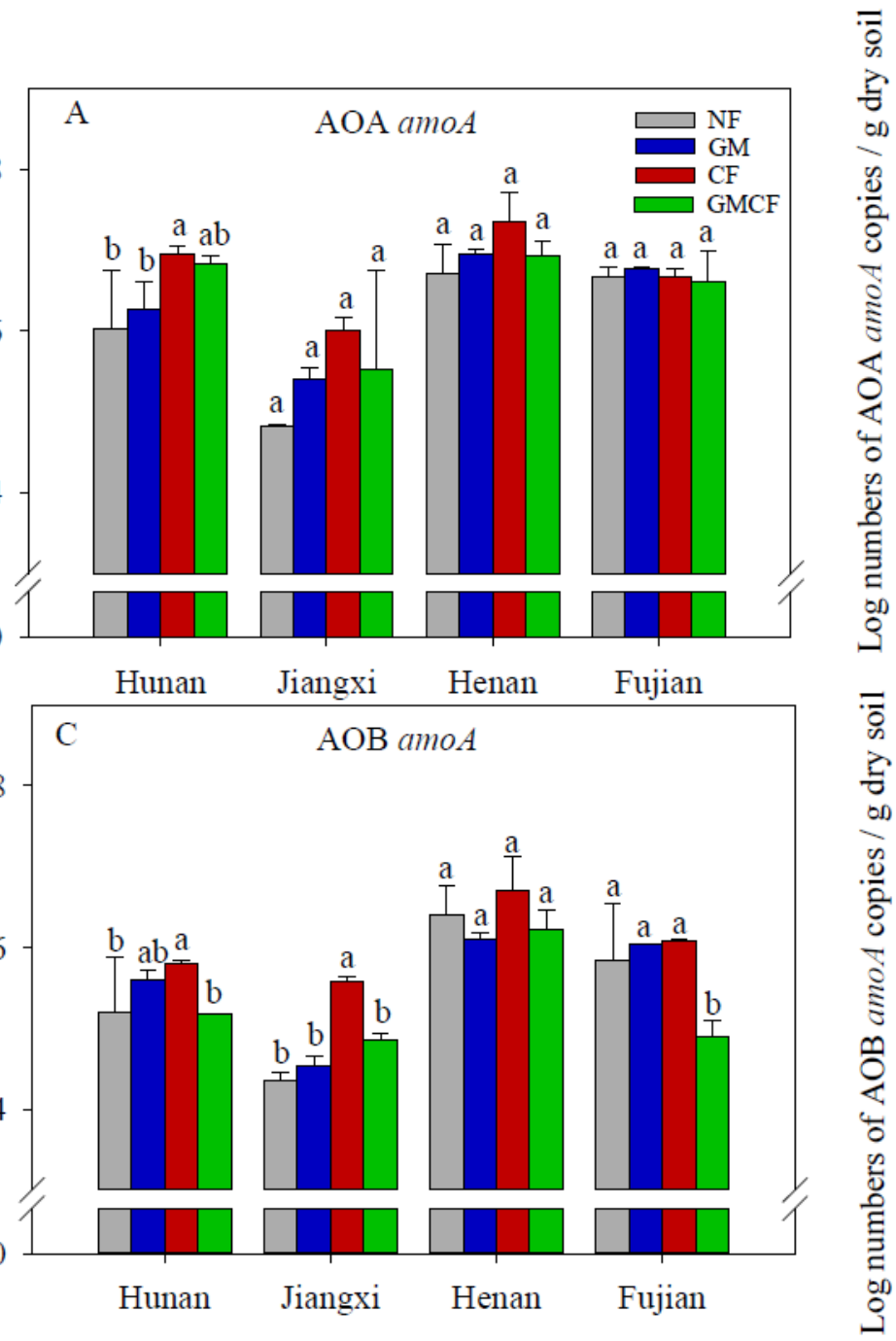

Site
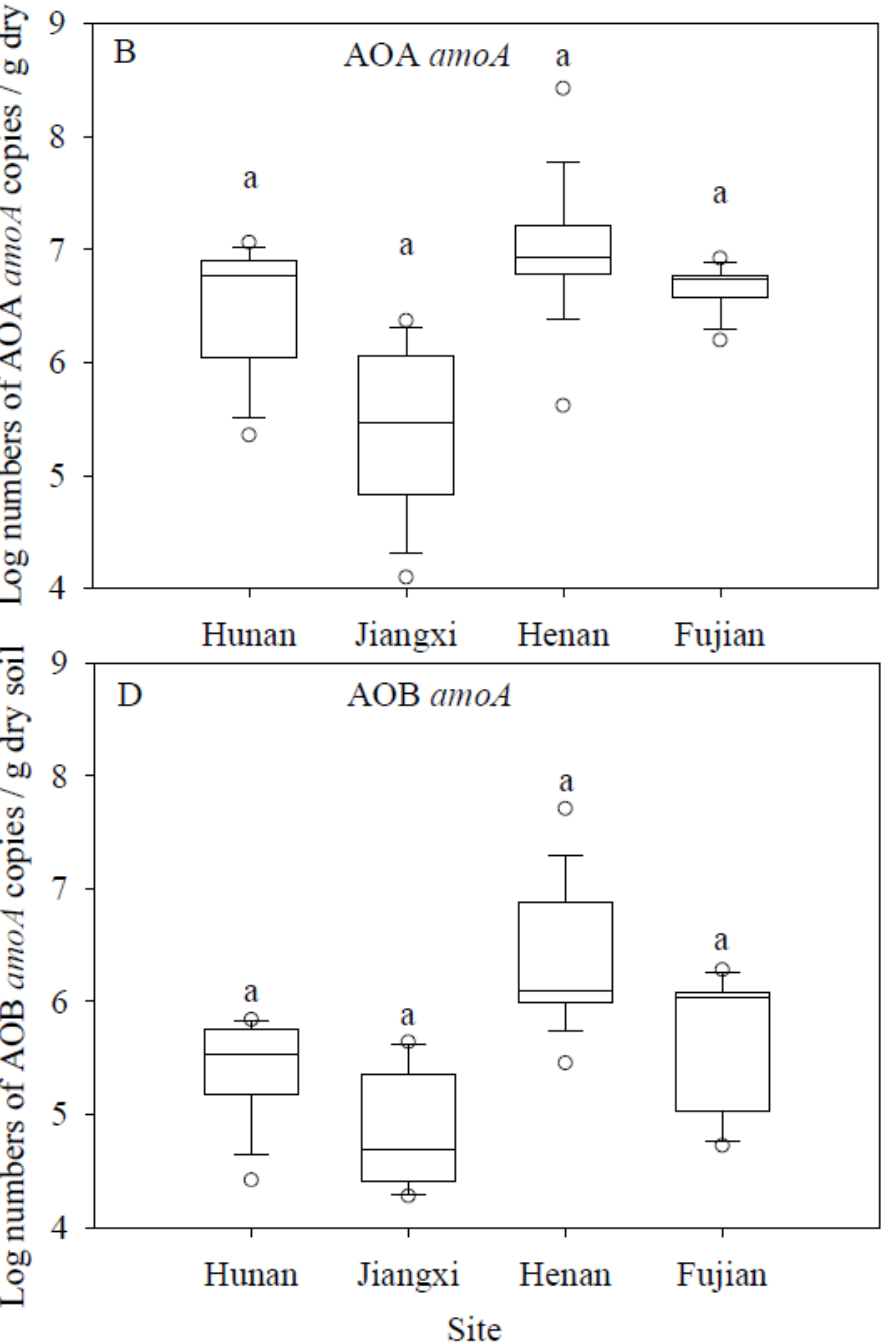

Figure 3

The abundance of archaeal $(A)$ and bacterial amoA gene in paddy soil under different treatments at the four sites (C), and the overall trends of the archaeal (B) and bacterial amoA gene abundance at the four sites (D). Vertical T bars in the histogram indicate SE. Vertical T bars in the Box-plot indicate maximum and minimum, respectively; circles represent outliers. Different letters indicate significant differences $(P<0.05)$ 


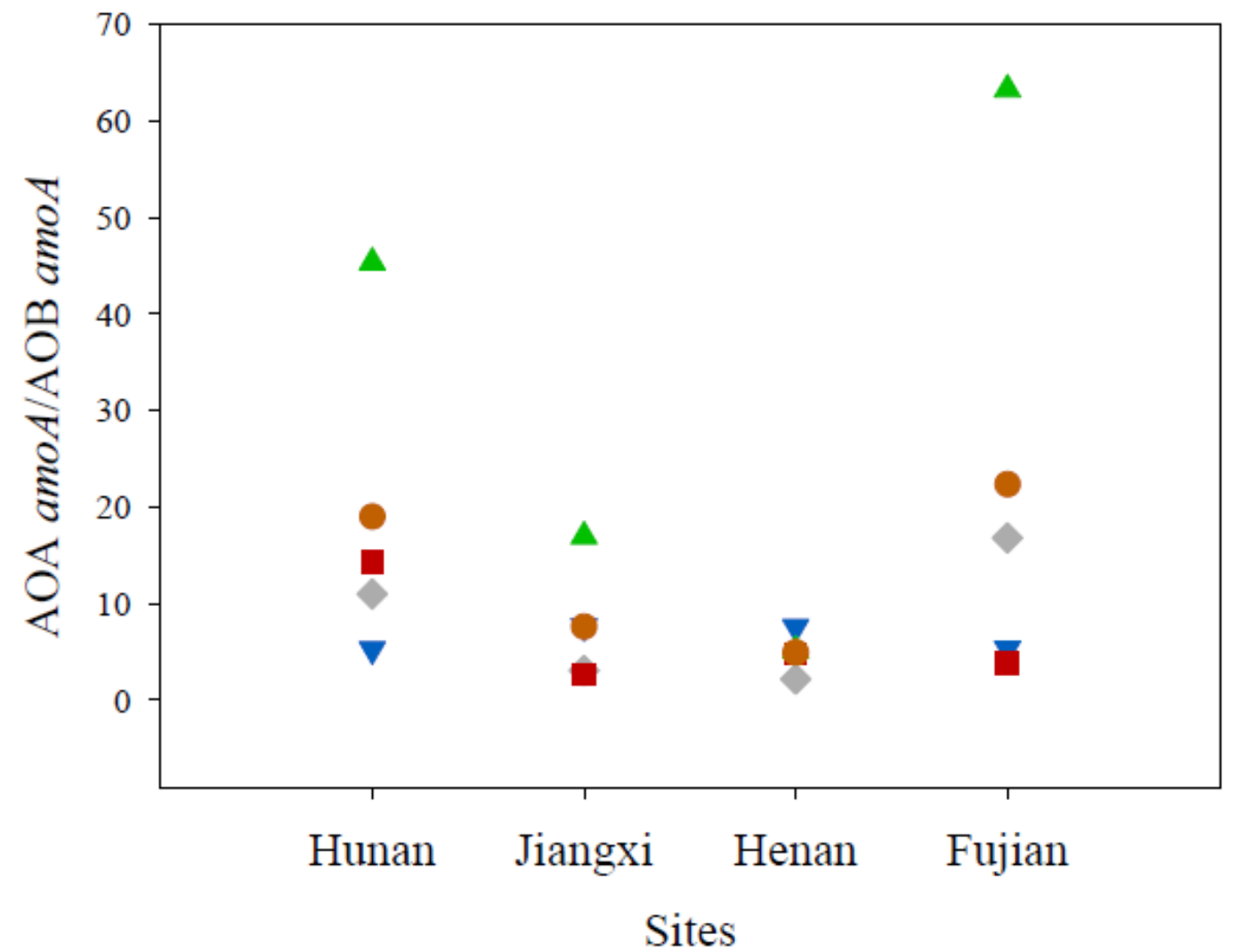

\section{Figure 4}

The values of $A O A$-amoA to $A O B$-amoA gene ratios under different treatments at the four sites. Average represents the average value of $A O A$-amoA to $A O B$-amoA gene in the site 

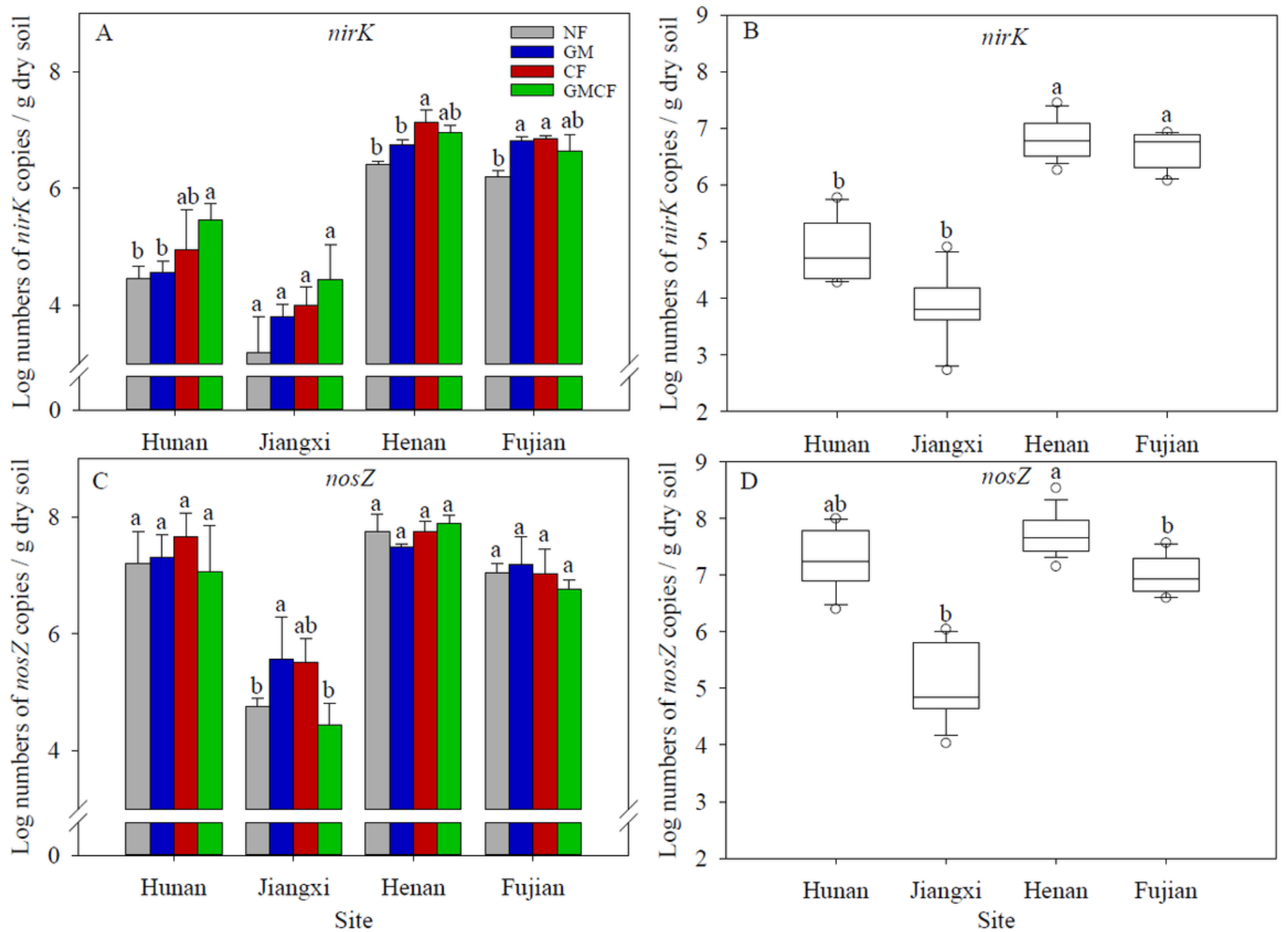

Figure 5

The abundance of nirk and (C) nosZ gene in paddy soil under different treatments at the four sites (A), and the overall trends of the nirK and (D) nosZ gene abundance at the four sites (B). Vertical T bars in the histogram indicate SE. Vertical $\mathrm{T}$ bars in the Box-plot indicate maximum and minimum, respectively; circles represent outliers. Different letters indicate significant differences $(P<0.05)$ 


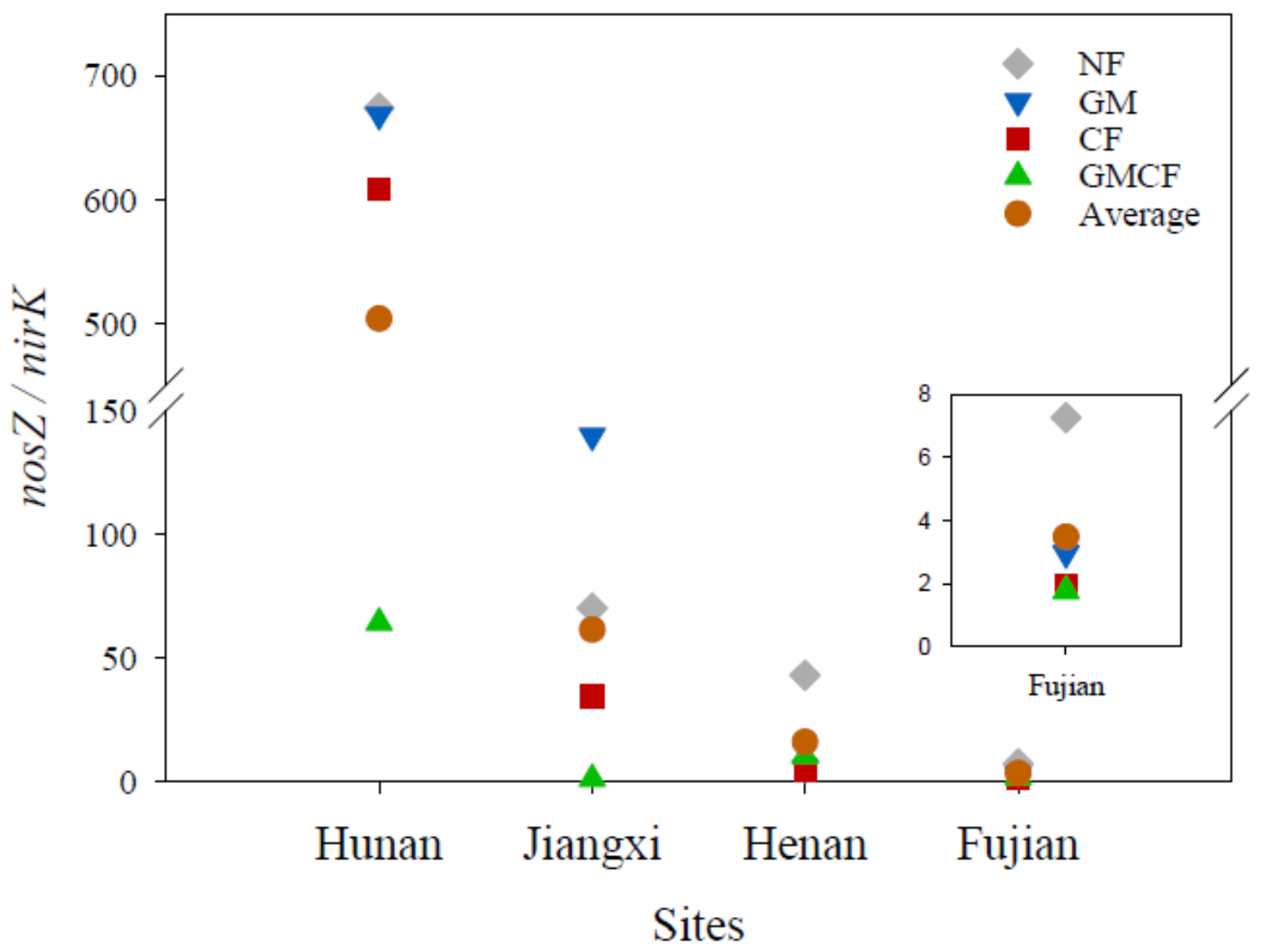

Figure 6

The values of nosZ to nirk ratios under different treatments at the four sites. Average represents the average value of nosZ to nirk in the site 


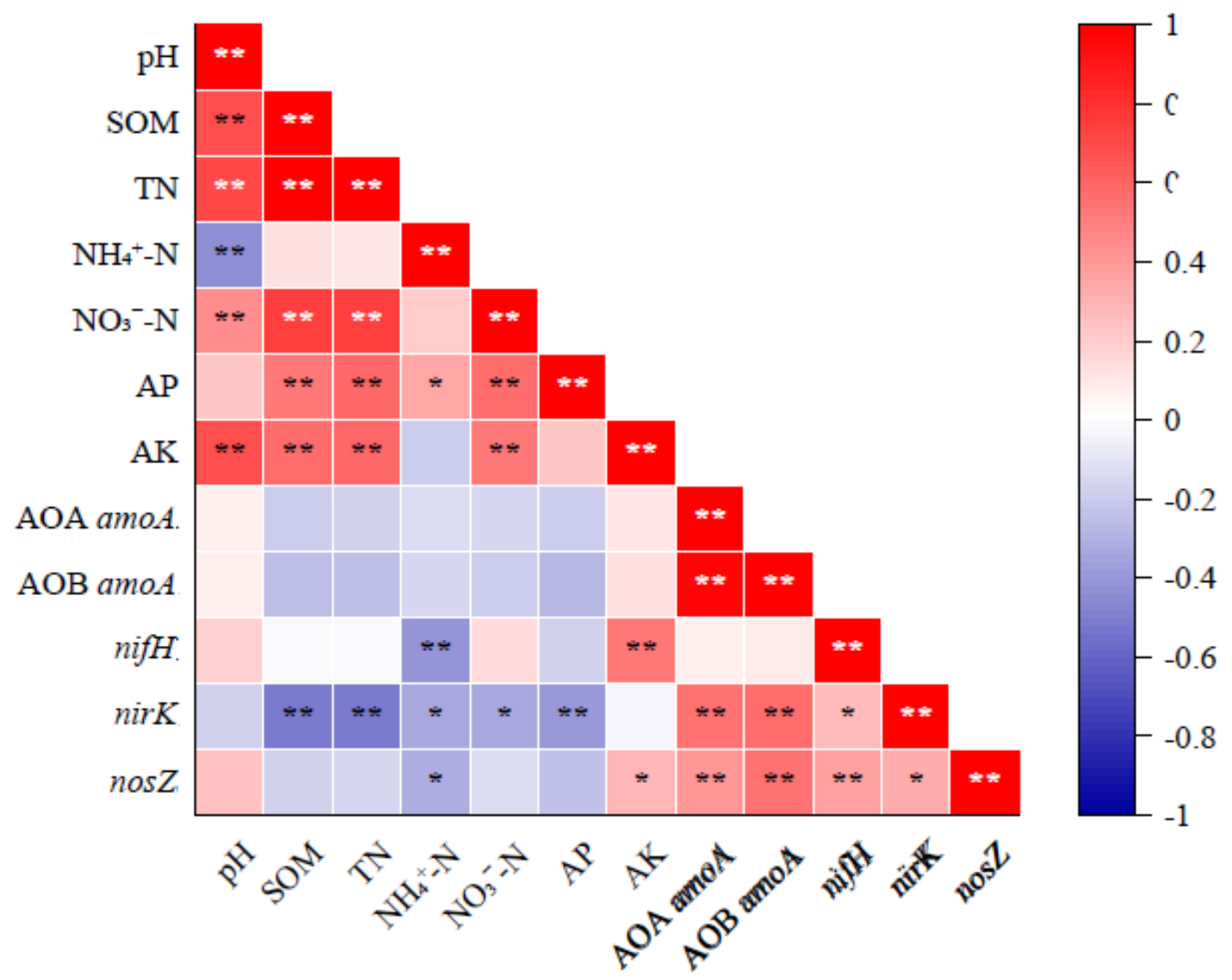

Figure 7

Calculated Pearson correlation coefficients ( $r$ ) between the functional genes and chemical properties of soils. * Represent significance at the 0.05 probability level, ** represent significant at the 0.01 probability level
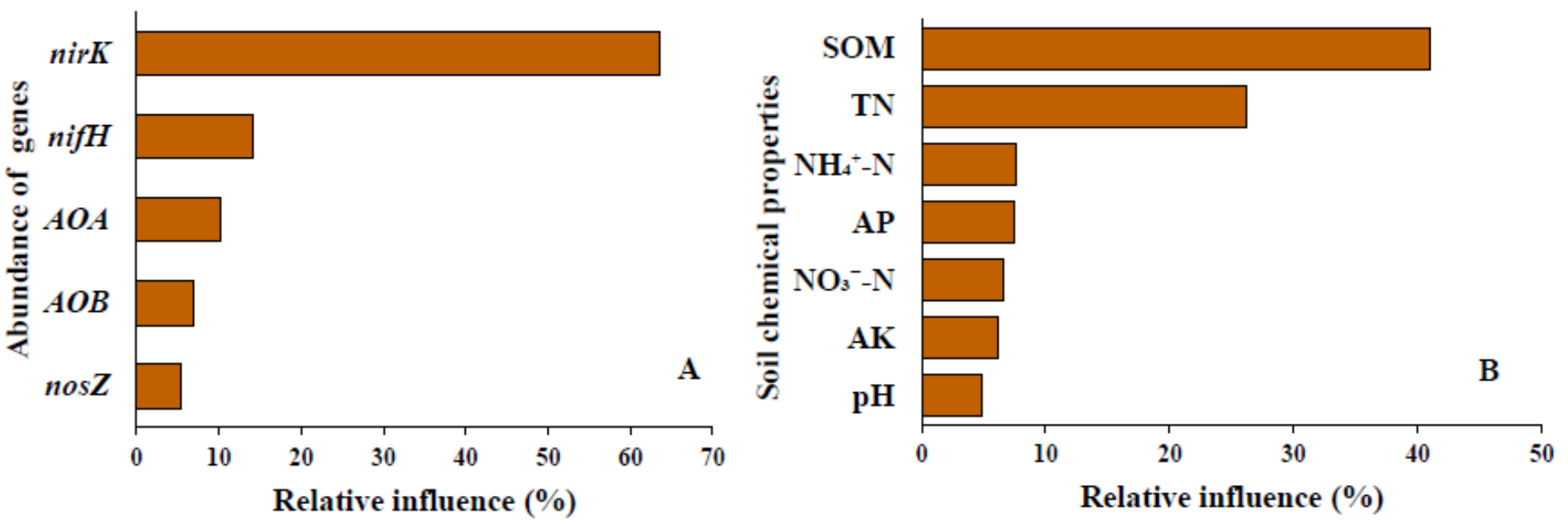

Figure 8

The relative influence of the functional genes involved in $N$ cycling $(A)$ and soil chemical properties (B) to rice yield 